\title{
Çölyak Hastalığına Diyetetik Yaklaşım
}

\section{Dietetic Approach to Celiac Disease}

Volkan Özkaya ${ }^{1}$,

Şebnem Özgen Özkaya ${ }^{2}$

${ }^{1}$ Uludağ Üniversitesi Sağlık Uygulama Araştırma Merkezi, Beslenme ve Diyet Birimi, ${ }^{2}$ T.C. Sağlık Bakanlığı Türkiye Kamu Hastaneleri Kurumu Dörtçelik Çocuk Hastalıkları Hastanesi, Beslenme ve Diyet Birimi

Geliş Tarihi/Received: 24 Haziran 2017 Kabul Tarihi/Accepted: 12 Ey/ül 2018

\begin{abstract}
Öz
Çölyak hastalığı hayat boyu devam eden tek besin intoleransıdır. Glutene karşı meydana gelen bu intolerans, ince bağırsağın yapısını bozmakta ve besin öğelerinin emilimini engellemektedir. Çölyak hastalığı, genellikle diğer otoimmün hastalıklarla ilişkilidir. Ülkemizde de sıklığı giderek artmaktadır. Farklı yaşlarda ve farklı klinik bulgularda karşımıza çıkabilmektedir. Günümüzde en etkili tedavi yöntemi, glutenin günlük diyetten çıkarılmasıdır. Tedavi aşamasında devreye giren glutensiz diyet, büyüme ve gelişmenin en hızlı olduğu dönemde bireyin tüm yaşamını etkilemektedir. Glutensiz diyetin sıkı bir şekilde uygulanmasıyla hastalıkla ilişkili düşük kemik mineral yoğunluğu ve bağırsak gastrointestinal sistem malign hastalıkları dahil bir çok komplikasyonun riski azaltılabilir, ancak glutensiz diyetin çocuk veya aile tarafından uygulanması ve takip edilmesi her zaman kolay değildir. Ayrıca glutensiz diyet bazı besin ögesi fazlalığına (doymuş yağlar), yüksek kalori alımına ve belirli besin ögelerinin (lif, folik asit, B12 vitamini, demir, çinko, magnezyum) yetersizliğine de neden olmaktadır. Özellikle glutensiz ürünler gluten içeren muadilleriyle karşılaştıııldıklarında hem magnezyum, lif ve folik asit içeriği daha düşük hem de daha pahalıdır. Diyet tedavisine "dirençli" olduğu düşünülen birçok hastanın da gluten içeren besinleri tükettikleri tespit edilmiştir. Bu nedenle glutensiz diyet iyi planlanmalı, aile ve çocuk eğitilmeli ve hasta uzun süreli takibe alınmalıdır. Bu derleme makalede Çölyak hastalığı, Çölyak hastalığında uygulanan diyet tedavisi, diyet tedavisinin ilkeleri, diyete uyum ve bu uyumu etkileyen faktörlere yer verilmiştir.
\end{abstract}

Anahtar Kelimeler: Çölyak hastalığı; gluten enteropatisi; glutensiz diyet; Çölyak ve beslenme

\begin{abstract}
Celiac disease is the only life-long lasting food intolerance. Intolerance, caused by gluten, endamages the structure of small intestine and prevents the absorption of nutritional elements. Celiac disease is usually related with other auto-immune diseases. Rate of disease in our country is increases by time. It can be seen in people of different ages and different clinical findings. Currently, the most efficient treatment is removal of gluten from daily diet. Gluten-free diet in treatment phase, affects quality of life of the individual for a period in which growth and development is most rapid. By applying the gluten-free diet strictly, the risk of complications like low bone mineral density and gastrointestinal system malignancies related with the disease, can be decreased. However, it is not always easy to apply and maintain gluten-free diet by family or child. Moreover, gluten-free diet can cause excess of some nutritional elements (saturated fat), high calorie intake and deficiency of some nutritional elements (fiber, folic acid, vitamin B 12, iron, zinc, magnesium). Particularly, gluten-free products, when compared with their gluten-including equivalents, have less magnesium, fiber, and folic acid, as well as they are far more expensive. It is determined that lots of patients considered as "resistant" to diet treatment are also taking gluten-including food. Therefore, gluten-free diet should be planned and followed well, and family and child should be educated. This editted article is about, Celiac disease, diet treatment for Celiac disease, principles of the diet treatment, concordance to the diet, and the factors that effects this concordance.
\end{abstract}

Keywords: Celiac disease; gluten enteropathy; gluten-free diet; Celiac and nutrition

\section{GíRiş}

Çölyak hastalığı $(C ̧ H)$, buğday, arpa, yulaf ve çavdarda bulunan gluten ve ilgili prolamine karşı aşırı duyarlılık sonucu gelişen, malabsorbsiyonla karakterize, ince bağırsak villuslarında total veya kısmi atrofi yapan, HLA-DQ2 ve HLA-DQ8 hallotip ve enteropatinin değişken bir kombinasyonunun varlığı ile karakterize immünolojik faktörlerin rol oynadığı bir hastalıktır $(1,2)$. İlk olarak 1888 yılında Samuel Gee tarafından tanımlanmış, 1950 yılında Dicke, hastalığın patogenezinde buğday ve çavdarda bulunan gluten isimli proteinin rolü olduğunu göstermiştir (3). Hastalığın görülme sıklığı coğrafi bölgelere göre değişmektedir. Buğday ve ürünlerinin fazlaca tüketildiği ülkelerde görülme sıklığı da artmaktadır. Türkiye'de ve Batı Avrupa, Kuzey
Amerika, Avustralya, Güney Batı Asya gibi bölgelerde daha sık görülmektedir (4). Yapılan epidemiyolojik çalışmalarda dünya çapında tahmini prevalansı \% 0.6-1 şeklinde bildirilmiştir $(5,6)$. Çölyak hastalığı prevelansı Finlandiya'da \% 2.4, Almanya'da \% 0.3, Cezayir'de \% 5.6 şeklinde bildirilirken, Türkiye'de ise yapılan bölgesel çalışmalarda \% 0.6-0,9 (1:158, 1/111) arasında tespit edilmiştir (7-10). Ancak ÇH'nın tanısal sıklığı artıyor olsa da hala buzdağının görünmeyen ve/veya tanı almayan kısmı büyük orandadır. Çölyak hastalığı tanısı alan her bir hastaya karşın 1:3-1:5 oranında tanı almayan ÇH bildirilmiştir (5).

\section{Gluten Nedir ve Hangi Besinlerde Bulunur?}

Gluten alkolde çözünen bir proteindir. Prolaminler ve polimerik gluteninler olmak üzere iki gruba

Yazışma Adresi: Volkan Özkaya, Uludağ Üniversitesi Sağıık Uygulama Araştırma Merkezi, Beslenme ve Diyet Birimi, Bursa 
ayrılmaktadır. Prolaminler buğdayda gliadin, çavdarda sekalin, arpada hordein, yulafta avenin ve mısırda ise zein olarak adlandırılmaktadırlar $(6,11)$. Hem gelişmiş hem de gelişmekte olan ülkelerin diyetlerinde buğday ve ürünlerinden gelen enerji günlük enerjinin büyük bir kısmını oluşturur. Buğday depo proteinlerinin yaklaşık \%80-85'ini gluten proteinleri oluşturmaktadır $(12,13)$; bu da günlük olarak büyük oranlarda glutene maruz kaldığımızı açıkça göstermektedir. Volta et al. (14) Akdeniz diyetinde yaklaşık olarak $20 \mathrm{~g} / \mathrm{gün}$ kadar gluten alındığını bildirmişlerdir. Ayrıca gluten, koruyucu ve visko-elastik özelliği nedeniyle gıda ve ilaç sanayisinde yoğun oranlarda kullanılır. Aromalar, gıda boyaları, emülgatör, rujlar, şampuanlar, diş macunları, losyonlar, posta pulları, bira mayası, dondurma, tatılar, şekerleme vb. ürünlerde gluten bulunur. $\mathrm{Bu}$ nedenle günlük hayatımızın her aşamasında glutene maruz kalınmaktadır (15).

Çölyak hastalığının klinik semptomları bebeklikte, çocuklukta, adolesan döneminde veya erişkinlik döneminde ortaya çıkabilir (12). Özellikle buğday ve türevlerinin çocuğun diyetine eklenmesinden sonra gelişir (2). Şiddetli malnütrusyondan Çölyak krizine kadar değişebilen geniş bir yelpazeye sahip klinik belirtileri vardır (7). Klinik bulgularına göre birçok sınıflandırma yapılsa da (klasik, atipik, asemptomatik, latent ve potansiyel $\mathrm{C} H$ ) The European Society for Paediatric Gastroenterology Hepatology and Nutrition (ESPGHAN) ÇH'nı sessiz, latent ve potansiyel ÇH şeklinde sınıflandırmaktadır. Sessiz ÇH, ÇH'ndan klinik olarak şüphelenilecek yeterli belirti ve bulgu olmaksızın pozitif ÇH'na özgü antikorlar, HLA ve ÇH ile uyumlu ince bağırsak biyopsisi bulgularının varlığı olarak tanımlanmıştır. Latent $\mathrm{ÇH}$, yaşamın herhangi bir döneminde glutene bağımlı enteropati geçiren bir hastada enteropati olmaksızın uyumlu HLA varlığı olarak tanımlanmıştır. Hastada semptomlar oluşabilir veya semptomlar gelişmeden de ÇH'na özgü antikorlar bulunabilir veya bulunmayabilir. Potansiyel $\mathrm{Ç} H$, ÇH'na özgü antikorlar ve uyumlu HLA varlığı olarak tanımlanmıştır. Hastada belirti ve bulgular bulunabilir ya da bulunmayabilir ve daha sonra glutene bağımlı enteropati gelişmesi göz önüne alınmadan hastalara ÇH tanısı konulabilmektedir (2).

\section{Risk Grupları}

Çölyak hastalığının gastrointestinal sistem (GiS) ve GiS dışı belirtileri büyük oranda proksimal ince bağırsakta gelişen emilim bozukluğuna bağlıdır. Gastrointestinal sisteme ait semptomlar doğumdan itibaren başlayabilir ancak semptomlar genellikle ek gıdaya başlanıldığı dönem ortaya çıkabilir. Büyüme ve gelişme geriliği, idiyopatik kısa boy, birkaç haftadan daha uzun süren ishal, kronik kabızıı, tekrarlayan karın ağrısı, kusma, pubertal gecikme, dermatit herpetiformis, tekrarlayan aftöz stomatit, anormal karaciğer biyokimyasal testler, kronik yorgunluk, tedaviye rağmen iyileşmeyen demir (Fe) eksikliği anemisi, diş mine hipoplazisi gibi durumlarda ÇH riski açısından çocukların taranması gerekmektedir (16). Çölyak hastalığı olan hastaların birinci derece akrabalarında ( \%10), HLAeşleştirilmiş kardeşlerinde ( \%30 -40), monozigotik ikizinde $(\sim 70)$, Tip 1 DM ve otoimmün tiroid hastalığı gibi otoimmün hastalıkları olan hastalarda, bazı kromozomal aberasyon bozukluklarında ve selektif IgA eksikliğinde ÇH prevelansının yüksek olduğu bildirilmiştir (17). Tip 1 DM'da ÇH prevalansı yoğun bir şekilde araştırılmıştır ve \% 3-12 şeklinde bulunmuştur (2). Ayrıca ek gıdaya erken veya geç başlayan bireylerde de ÇH riski artmaktadır. Dört aydan önce veya 7 aydan sonra glutenin diyete girişi ÇH riskini artırmaktadır. ESPGHAN, bebeklerin 4-7 ay arasında glutenle tanıştırılmasını önermektedir (2, 18). Mevsimsel farklılıklara bakıldığında kış aylarında doğan çocukların yaz aylarında doğan çocuklara göre ÇH riski daha yüksektir. Özellikle enfeksiyon, rotavirüs-adenovirüs enfeksiyonu sıklığı arttıkça ÇH riski de artmaktadır $(19,20)$. Anne sütü ile beslenme veya beslenmeme de önemli bir etkendir. Yapılan çalışmalarda uzun süre anne sütü ile beslenme ÇH'dan korunmada önemli bir etkenken, anne sütü almama ise ÇH oluşmasında bir risk faktörü olarak görülmektedir. Risk teşkil eden diğer bir faktör de alınan glutenin miktarıdır. Az veya orta miktarda glutenle tanıştırılan çocukla yüksek miktarda glutenle tanıştırılan çocuklar incelendiğinde yüksek miktar gluten alan çocuğun ÇH açısından yüksek riske sahip olduğu bildirilmiştir $(21,22)$.

\section{Çölyak Hastalığı Tanısı}

Çölyak hastalığı tanısında kullanılmak üzere oluşturulan antikor testleri kanda anti-TG2 veya Anti-Endomiziyal Antikorları (EMA) ölçer. Referans standardı ile \%95'ten fazla uyum gösteriyorsa güvenilir kabul edilir (Tablo 1). EMA gibi immünofloresan testlerin özgüllüğü, uzman laboratuarlarda \% 98100 arasındadır ve bu test ÇH'na özgü antikorun belirlenmesi için standart referans olarak kabul edilir. Bunun dışında HLA-DQ2 ve HLA-DQ8 tip tayini de ÇH tanısı koymaya yardımcı olabilir; ancak kesin tanı için ince bağırsak biyopsisi şarttır $(2,8)$. 
Table 1. PPH Yönetiminde Kanıta Dayalı Yaklaşımlar

\begin{tabular}{llll}
\hline Test & Duyarlılık(aralık) & Özgüllük (aralık) & Öneriler \\
\hline IgA anti-tTG antikorlar & $>95,0(73,9-100)$ & $>95,0(77,8-100)$ & İlk düzey tarama testi için önerilir \\
IgG anti-tTG antikorlar & Geniş aralıkta $(12,6-99,3)$ & Genişaralıkta $(86,3-100)$ & IgA yetersizliği alan hasta için uygun \\
IgA anti-endomysial antikorlar & $>90,0(82,6-100)$ & $98,2(94,7-100)$ & Kesin olmayan tanılarda uygun \\
IgG DGP & $>90,0(80,1-98,6)$ & $>90,0(86,0-96,9)$ & IgA yetersiz olan ve genç çocuklarda uygun \\
HLA-DQ2 ve HLA-DQ8 & $91,0(82,6-97,0)$ & $54,0(12,0-68,0)$ & Yüksek negatif tahmini değer \\
\hline
\end{tabular}

\section{Çölyak Hastalığının Tedavisi}

Çölyak hastalığı tüm dünyada en sık görülen kronik ve otoimmün bir hastalık olması nedeniyle küresel bir sağlık sorunu olarak ele alınmaktadır. Günümüzde ÇH'nın tek tedavi yöntemi ömür boyu glutensiz beslenmedir. Kesin ve net bir diyet uygulanmalıdır. Diyetten tamamen buğday, arpa ve çavdarın çıkarılması gerekir $(11,23,24)$. Yulaf konusunda ise hala soru işaretleri mevcuttur. En çok, yulafın kontaminasyon riskinden dolayı ÇH'da diyetten çıkartılması gerektiği söylenmektedir. Ancak bir grup hastanın saf yulafı tolere edebildiği bildirilmiştir (yetişkinlerde $70 \mathrm{~g} / \mathrm{gün}$ ve çocuklarda $25 \mathrm{~g} / \mathrm{gün}$ ) (8). Yulaf tüketimi lif, B grubu vitaminler, magnezyum ve demir alımını artırarak ÇH diyetlerinin besin değerini geliştirir. Ancak yine de yulaf kullanan hastaları dikkatle izlemek gerekmektedir (11). Pirinç, mısır, baklagiller, et, balık, yumurta, patates, soya fasulyesi, meyve ve sebzeler gluten içermezler ve hastalar diyetlerinde serbest olarak tüketilebilirler. Hazır ürünlerde gluten visko-elastik özelliği nedeniyle bağlayıcı olarak kullanıldığından etiket bilgilerinin okunması gerekmektedir (23). Laktaz enzim havuzu azalmış olan ÇH'da ilk 3 ay laktozsuz diyet önerilmektedir (11). Yapılan çalışmalarda ÇH'da $50 \mathrm{mg} / g u ̈ n ~ k a d a r$ gluten alımının bağırsak mukozası, villus yükseklik / kript derinliği oranında önemli azalmaya neden olduğu ve bu nedenle çok düşük düzeyde gluten alımının bile Çölyak hastalarında immünojenik yanıta neden olduğu bildirilmiştir. En iyi glutensiz diyet, 20 ppm den daha az gluten içermesiyle mümkündür. Bir ince dilim ekmek yaklaşık 1,6 g gluten içerir (8, $24,25)$. Bu nedenle tüm yiyecekler, içecekler, ilaçlar vb. tüm tüketilen ürünlerden glutenin çıkarılması gerekmektedir. Codex Alimentarius'da; düşük glutenli gıdalar $20-100 \mathrm{mg} / \mathrm{kg}$, glutensiz gıdalar $<20 \mathrm{mg} / \mathrm{kg}$ olarak tanımlanmaktadır (26).

Tanıdan sonra glutensiz diyete geçilmesi ve tam uyum sonrası ilk 2 hafta içinde hastalık yakınmalarında $\% 70$ azalma, 6 ay içinde serolojik testlerde düzelme, 6-24 ayda ise histolojik düzelme gerçekleşebileceği bildirilmektedir $(24,27)$. Ancak hastaların diyete uyumlarında sorun varsa veya glutensiz diyete geçiş yapılmadıysa; büyüme geriliği, boy kısalığı, mikro/makronutrient eksiklikleri, anemi, yüksek aminotransferaz düzeyleri, eklem / kas ağrısı, osteoporoz, diş minesi bozuklukları ve diğer otoimmün hastalıkların risklerinde artışın yanı sıra ileri yaşlarda kızlarda infertilite, spontan abortus, erken doğum ve düşük doğum ağırlıklı bebeklerin olabileceği bildirilmiştir (28).

\section{Glutensiz Diyet ve Makrobesin Dengesizlikleri}

Çölyaklı çocuklarda sağlıklı ve dengeli beslenme için önerilen günlük kalori alımının tavsiye edilen dağılımı, genel nüfusa önerilenden farklı değildir. Genellikle, hastalar yüksek yağ, şeker ve kalori içeren besinlere diyetlerinde yer vermektedir. Glutensiz ürünler genellikle gluten içeren muadillerine göre daha yüksek karbonhidrat ve lipid içeriğine sahiptirler. Glutensiz ekmeklerin besin kompozisyonları incelendiğinde bu ekmeklerin düşük protein, yüksek yağ ve yüksek glisemik indekse sahip olduğu bulunmuştur. Glutensiz bisküvilerin ise gluten içeren muadillerine göre doymuş yağ asitlerince zengin olduğu tespit edilmiştir $(23,29)$. Bu nedenle doğal karbonhidrat kaynakları olarak patates, alternatif tahıl olarak fasulye, bakliyat ve nişastalı sebzeler gibi doğal ürünler kullanarak mevcut karbonhidrat alımı sürdürülmelidir. Çölyak hastalığı diyetinde doğal besinlere ağırlık verilerek yüksek yağ, şeker ve kalori alımından kaçınılmalıdır (23). Ayrıca laktaz enzim havuzu azalmış olanlarda (hastaların \% 30-60'da) belirli süre laktozsuz diyet planlanmalı, diyetlerinden süt uzaklaştırılmalıdır. Hastalarda malabsorbsiyondan kaynaklanan belirgin bir kilo kaybı ve besin öğesi eksikliği nedeniyle tedavinin başlangıcında protein ve enerji açısından zengin bir diyet planlanabilir (15). Bireysel günlük enerji ihtiyacı, yaş, cinsiyet ve fiziksel aktivite göz önüne alınarak belirlenmelidir. Enerjinin $\%$ 45-65'i karbonhidratlardan, \% 10-35'i proteinlerden sağlanmalıdır. Protein kaynakları olarak kuru fasulye ve baklagiller, yağlı tohumlar, balık, kümes hayvanları, yumurta, kırmızı et, yağsız veya az yağlı süt, amaranth ve kinoa gibi tahıllar kullanılabilir. Toplam yağ alımı enerjinin \% 20-35'i arasında tutulmalı, trans yağlar ise mümkün olduğu kadar az tüketilmelidir (toplam 
kalori alımının \% 1'i kadar). Doymamış yağlar (tekli doymamış ve çoklu doymamış) tercih edilmelidir. Doymuş yağ alımları da sınırlandırılmalıdır (15, 23, 30). Yapılan çalışmalarda Çölyak hastası ergenlerin çoklu doymamış yağ asitlerince zengin beslendikleri bildirilmiştir $(31,32)$. Öğün sayısı hastanın yaşam tarzına ve alışkanlıklarına göre 3-6 öğün olacak şekilde planlanmalıdır (15).

\section{Glutensiz Diyet ve Lif Alımı}

Çölyaklı hastalarda kronik kabızlık yaygın olarak görülmektedir. Bunun nedeni hastaların lif alımlarının önerilenden düşük olmasıdır. Diyet lifi sindirime dirençli bitki materyali ve moleküllerin karmaşık bir karışımıdır. Koroner kalp hastalığı, diyabet, kolon kanseri ve benzeri hastalıkların önlenmesinde yüksek lifli diyetin yararlı etkisi olduğu bilinmektedir $(33,34)$. Glutensiz ticari tahıl bazlı ürünlerin büyük çoğunluğu, gluten içeren muadillerine göre önemli ölçüde daha az lif içermektedir. Birçok ticari glutensiz besin rafine un ve/veya nişasta bazlıdır. Bu da Çölyak hastalarının dolaylı olarak daha düşük lifli beslenmesine katkı sağlamaktadır. Çölyak hastalarına lif açısından daha zengin olan kahverengi pirinç, yabani pirinç, kinoa, yulaf, amaranth, darı, sorgum ve teff gibi tahıllar önerilebilir. Günlük tahıl porsiyonunun en az yarısı tam tahıllı kaynaklardan gelmelidir. Çölyak hastalarının genel popülasyona önerilen kadar lif almaları sağlanmalı, Recommended Dietary Allowance (RDA) referans alınmalıdır (1-3 yaş $19 \mathrm{~g} / \mathrm{gün}, 4-8$ yaş $25 \mathrm{~g} /$ gün, 9-18 yaş 26-38g/gün) (23).

\section{Glutensiz Diyet ve Mikrobesin Dengesizlikler}

Çölyak hastalarıyla yapılan çalışmalarda hastaların birçoğunda mikrobesin öğelerinin yetersizliği saptanmıştır. Bunun iki nedeni vardır: ilk olarak villöz atrofisine bağlı malabsorbsiyonlar, ikincil olarakda diyetle yeteri kadar mikrobesin ögesi alınamamasıdır (23). Ancak diğer bir gerçek de uygun diyete rağmen uzun süreli mikrobesin yetersizliklerinin devam etmesidir (35). En çok karşılaşılan mikrobesin yetersizlikleri A, D, E, K, B1, B2, B6, B12, Folat vitamini, demir, kalsiyum ve çinko gibi minerallerdir.

Demir (Fe) yetersizliği, Çölyak hastalarında en sık görülen mikrobesin ögesi yetersizliğidir. Hastalarda açıklanamayan anemi ÇH ayırıcı tanısında düşünülebilir. Çölyak hastalığı tanılı hastaların yaklaşık olarak \% 49'da Fe eksikliği; Fe eksikliği anemisi nedeniyle tedavi almış hastaların yaklaşık \%8'de de ÇH tespit edilmiştir (15). Tedaviyle birlikte Fe yetersizliği ve anemi geriler; ancak çoğu hastaya ek öneriler sıkça gerekir $(36,37)$. Demir yönünden zengin besinler glutensiz diyette yer almalıdır. Bunlar; hayvansal protein ve demir ile zenginleştirilmiş deniz ürünleri, kinoa, amaranth, teff, koyu yeşil yapraklı sebzeler, fındık ve yağlı tohumlar, glutensiz makarna, tahıl ve glutensiz ekmektir $(38,39)$. Anemi genellikle 6 ay sürse de 12 ay boyunca takviye verilmesi önerilir. Oral replasman tedavisine yanıt vermeyen Fe eksikliği anemisi hastalarını tedavi ederken diğer faktörler de göz önüne alınmalıdır (mide asiditesi, Fe emilimini engelleyen faktörler, kan kaybı). Demir emilimini artırmak için $\mathrm{C}$ vitamini takviyesi de yararlı olmaktadır (40). Çölyak hastasının yaş, cinsiyet ve sağlık durumu gibi faktörler göz önünde bulundurularak demir desteğinin sağlanması önemlidir. Gerekirse RDA önerileri dikkate alınmalıdır (23).

B12 vitamini eksikliği Çölyak hastalarında yüksek oranda görülmektedir. B12 yetersizliği prevelansı Çölyak hastalarında \% 8-41 arasında değişmektedir (15).

Magnezyum (Mg) yetersizliği de diyete uyulmadığında görülen bir diğer yetersizliktir. Magnezyum eksikliği gelişme geriliği, kardiyovasküler disfonksiyon ve davranış bozukluklarına neden olabilir. Magnezyumun ana kaynağı süt ve süt ürünleri, ekmek, et, kümes hayvanları, balık ve yumurta gibi besinlerdir. Ekmek ile günlük Mg intiyacının \% 12'si karşılanmaktadır. Nitekim glutensiz ekmek normal ekmekle karşılaştırıldığında yaklaşık \% 80 daha az $\mathrm{Mg}$ içermektedir. Bu nedenle glutensiz ekmeklerin $\mathrm{Mg}$ ile zenginleştirilmesi önerilir (31).

Folat emilimi öncelikle jejunumda gerçekleşir. Çölyak hastalığında mukozal hasar oluştuğundan folat emilimi de bozulmuştur. Folat, aminoasit ve nükleik asit metabolizması için önemlidir. Normal vücut folat depoları vitamin B12 depoları ile karşılaştırıldığında 2-4 ay içinde tükenir. Yorgunluk, ishal, nefes darlığı, sinirlilik, iştahsızlık, unutkanlık ve kilo kaybı folik asit eksikliği belirtileridir. Folik asit emilim bozukluğu ve anemi gibi durumlarda takviyesi önerilir. Glutensiz diyete geçiş ve uygun takviye ile birlikte 4-6 ay içerisinde konsantrasyonu yükselmektedir(41).

Hem D vitamini ve hem de kalsiyum (Ca) eksiklikleri ÇH'da sık görülmektedir. Özellikle ÇH'nın ilk dönemlerinde ve sonraki süreçte devam eden laktoz intoleransı nedeniyle Ca yeteri kadar alınamamaktadır. Ayrıca emilim bozuklukları da yetersizliğe katkı sağlamaktadır. Buna bağlı olarak ÇH'da osteoporoz oldukça yaygındır. Yeni tanı konmuş tüm hastalarda kemik yoğunluğu ölçülmelidir. Hastaların gereksinimi karşılanmalı, kemik hastalığının şiddetine bağlı olarak 
Table 2. Besin Öğesi Eksiklikleri ve Tedavi Önerileri

\begin{tabular}{|c|c|c|c|}
\hline Besin Öğesi & Epidemiyoloji & Test Önerileri & Tedavi Önerileri \\
\hline Demir & $\begin{array}{l}\text { Tanı alan hastaların } \\
\% 28-50 \text { 'sinde yetersiz. } \\
\text { En yaygın ekstraintestinal } \\
\text { göstergelerden birisidir }\end{array}$ & $\begin{array}{l}\text { Tanıda serum demir } \\
\text { ve ferritin bakılmalı. } \\
\text { Ferritin normal düzeye } \\
\text { gelene kadar } 3-6 \text { ayda } \\
\text { bir tekrarlanmalı. Sonra } \\
\text { her } 1-2 \text { yılda veya } \\
\text { semptonlar olduğunda }\end{array}$ & $\begin{array}{l}\text { Demir süplemantasyonu } \\
\text { (325mg) 1-3tablet, başlangıç } \\
\text { ferritin düzeyine göre ve demir } \\
\text { düzeyi düzelene kadar. İleri } \\
\text { düzey semptomatik demir } \\
\text { yetersizliği anamesi ve } \\
\text { oral demir alımına intolerans } \\
\text { olduğunda IV demir düşünülmeli }\end{array}$ \\
\hline Vitamin D & $\begin{array}{l}\text { Tanı alan hastaların } \\
\% 20-66 \text { 'sında düşük } \\
\text { düzeyde görülür. Son } \\
\text { raporlara göre fazla güneş } \\
\text { alan bölgelerde bile } \\
\text { yetersizlikler mevcuttur }\end{array}$ & $\begin{array}{l}\text { C vit }(25 \mathrm{OH}) \text { düzeyi } \\
\text { tanıda bakılmalı. D vit } \\
\text { düzeyi normale kadar } \\
\text { her } 3 \text { ayda bir tekrarlanır. } \\
\text { Sonra her } 1-2 \text { yılda veya } \\
\text { semptonlar olduğunda }\end{array}$ & $\begin{array}{l}\text { D vit düzeyine göre } 1000 U \\
\text { veya fazlası/gün } \\
\text { düzey<20ng/ml ise } \\
\text { D2 vit } 50,000 U / \text { hafta }\end{array}$ \\
\hline Folik Asit & $\begin{array}{l}\text { Tanı alan hastaların } \\
\% 18-42 \text { 'sinde yetersizlik } \\
\text { görülmekte. Kuzey } \\
\text { amerika'da yetersizlik nadir }\end{array}$ & $\begin{array}{l}\text { Riskli popülasyonlarda } \\
\text { serum folat düzeyi tanıda } \\
\text { bakılmalı. Gebelik planlayan } \\
\text { her kadında kontrol edilmeli }\end{array}$ & $\begin{array}{l}\text { Folik asit: } 1 \mathrm{mg} / \mathrm{kg} / 3 \text { ay } \\
\text { Daire gelişirse } \\
400-800 \mu \mathrm{g} / \mathrm{gün}\end{array}$ \\
\hline Vitamin B12 & $\begin{array}{l}\text { Tanı alan hastaların } \\
\text { \%8-41'inde yetersizlik } \\
\text { görülmekte. İkincil } \\
\text { bakteriyel çoğalmayı } \\
\text { da düşündürür }\end{array}$ & $\begin{array}{l}\text { Tanıda serum B12 } \\
\text { düzeyine bakılmalı. Sonra } \\
\text { her } 1-2 \text { yılda veya } \\
\text { semptonlar olduğunda }\end{array}$ & $\begin{array}{l}\text { B12 düzeyi normal olana kadar } \\
\text { oral olarak } 1000 \mu \mathrm{g} \text { Daha sonra } \\
\text { günlük glutensiz mutli vitamin- } \\
\text { mineral suplementasyonu }\end{array}$ \\
\hline Çinko & $\begin{array}{l}\text { Yeni tanı almış } \\
\text { çölyaklıların \%54-67'sinde } \\
\text { yetersizlik görülmekte }\end{array}$ & $\begin{array}{l}\text { Tanıda serum çinko } \\
\text { düzeyine bakılmalı. } \\
\text { Çinko düzeyi normale } \\
\text { olana kadar tekrarlanır. } \\
\text { Sonra her } 1-2 \text { yılda veya } \\
\text { semptonlar olduğunda }\end{array}$ & $\begin{array}{l}\text { Çinko düzeyi normal olana } \\
\text { kadar en az 25-40mg/gün }\end{array}$ \\
\hline Kalsiyum & $\begin{array}{l}\text { Hastaların \%50'sinde } \\
\text { önerilen Ca miktarından } \\
\text { daha az tüketmekte }\end{array}$ & $\begin{array}{l}\text { Diyetisyen tarafından } \\
\text { düzenli diyet değerlendirmesi }\end{array}$ & $\begin{array}{l}\text { Diyet + suplementasyon } \\
1,200-1,500 \mathrm{mg} / \mathrm{gün}\end{array}$ \\
\hline Diyet lifi & $\begin{array}{l}\text { Glutensiz diyet } \\
\text { konstipasyona neden } \\
\text { olduğunda yetersizlik rapor } \\
\text { edilmiştir. Yetersizlik her } \\
\text { iki cinsiyette ve Amerika } \\
\text { gibi avrupada da rapor } \\
\text { edilmiştir. }\end{array}$ & $\begin{array}{l}\text { Diyetisyen tarafından } \\
\text { düzenli diyet değerlendirmesi }\end{array}$ & $\begin{array}{l}\text { Yaş ve cinsiyete göre } \\
25-35 \mathrm{~g} / \mathrm{gün} \text { Yüksek posa } \\
\text { içeren alternatif tahılların } \\
\text { yeterli su ile alımı önerilmelidir. }\end{array}$ \\
\hline
\end{tabular}

Tüm suplemanlar glutensiz olmalıdır. Kalsiyum ihtiyacı yaş ve medikal duruma göre değişebilir. Diyet kalsiyumuna ek olarak, kalsiyum ihtiyacını karşılamak için suplementasyon önerilebilir.

gereksinimin üstünde $\mathrm{Ca}$ ve $\mathrm{D}$ vitamini verilmelidir. Kemik yoğunluğunu artırmak ya da daha fazla kemik kaybını önlemek için hastalara uygun ilaç destekleri ve egzersiz planlanmalıdır. En uygun egzersiz yürüyüş, dans, koşu, direnç ve ağırlık egzersizleridir (40). Günde 3 porsiyon az yağlı veya yağsız süt ve ürünlerinin diyette yer alması önerilmektedir. Laktoz intoleransı olan Çölyak hastalarına ise hastanın klinik tablosu göz önünde bulundurularak RDA önerileri kadar Ca ve $\mathrm{D}$ vitamini takviyesi yapılmalı ve hastalar uzun süreli takip edilmelidir $(15,23,42)$. (Tablo 2)

Et, balık, sebze ve meyve; vitamin, mineral ve eser elementlerin önemli bir doğal kaynağıdır. Glutensiz diyet ile ilişkili olası mikrobesin ögesi eksikliğinde bu gıdaların uygun bir kompozisyonda tüketilmesi ÇH'li çocuklara tavsiye edilmelidir. Özellikle meyve ve sebzeler vitamin ve mineraller açısından zengin, enerjisi düşük, fitokimyasal maddeleri ve antioksidan bileşikleri içeren ve oksidatif hasara karşı koruyucu birçok öge içermektedir. Meyve ve sebzenin günde en az 5 porsiyon tüketilmesi ÇH'li çocuklara tavsiye edilmelidir. Mineraller (kalsiyum, fosfor, sodyum, potasyum, klorür ve magnezyum) ve eser elementler (demir, çinko ve selenyum) açısından zengin 
Table 3. Amaranth, Kinoa ve Buğdayın Besin Kompozisyonları

Yüksek posa içeriği, 7-10 g/ $100 \mathrm{~g}$, buğday lifi 9,5 g/ $100 \mathrm{~g}$ ile yaklaşık olarak aynı.

Yüksek protein içeriği, kuru kütlesinin \% $10.9-15,2$, buğday kuru kütlesinin \% 11.7.

Yüksek kaliteli amino asitler lisin, arginin, histidin, sistein ve metionin.

Özellikle, $\alpha$-linolenik asit, doymamış yağ asitleri kaynağıdır.

Yüksek folik asit içeriği buğdayda 40 mikrogram / $100 \mathrm{~g}$ sırasıyla kinoa ve amaranth, 78.1 mikrogram/100 g ve 102 mikrogram / $100 \mathrm{~g}$,

Vitaminler içerir: B2, B6, riboflavin, vitamin C ve E

Minerallerin kaynağı: İçerik, diğer tahıl iki kat yüksektir.

* Amaranth ve kinoa besin içeriği buğday ile karşılaştırılmıştır.

tahılların glutensiz diyette yer alması mikrobesin yetersizliklerinin önlenmesinde etkili olabilir. Örneğin amaranth ve kinoa, buğday ile karşılaştırıldığında buğdaya göre daha fazla folik asit içermektedir (buğday $40 \mu \mathrm{g} / 100 \mathrm{~g}$, kinoa $78.1 \mu \mathrm{g} / 100 \mathrm{~g}$ ve amaranth $102 \mu \mathrm{g} / 100 \mathrm{~g}$ ). Yüksek lif içeriği de buğday lifi ile benzerdir (7-10 g/100 g, buğday lifi 9,5 g/100 g) (30). Diğer içerikleri de Tablo 3'de gösterilmiştir.

Ayrıca ticari olarak satılan glutensiz ürünlerle karşılaştırıldığında amaranth ve kinoanın daha ekonomik olması, hastanın ekonomik yükünü azaltarak diyete uyumunu artırmakta ve diyette çeşitliliği sağlayarak sağlıklı alternatifler oluşturmaya yardımcı olmaktadır (30).

\section{Glutensiz Diyet ve Kilo Kontrolü}

Çölyaklı hastalarda tanıdan önce malabsorbsiyon ve yetersiz beslenmeye bağlı kilo kaybı ve düşük ağırlıklar görülmektedir. Ancak ÇH tanısı ve glutensiz diyete geçişle birlikte kilo artışları da gerçekleşmektedir. Uygun planlanmayan diyet ve hastaların yüksek yağlı ticariglutensiz aperatifleri ve bisküvileri aşırı tüketimine bağlı BKI artışları iki katına kadar çıkabilmektedir (23, 40). Birçok çalışmada GFD başlanmasından sonra BKl'de anlamlı artışlar bildirilmiştir. Tanıda normal kilolu olan hastaların yaklaşık \% 22'de GFD sırasında ağırlık artışı gerçekleşmiştir (43). Çölyak hastalarında sık görülen düşük kilo ve diyareye tezat olarak GFD ile birlikte hastaların \% 30'da aşırı kiloluluk ve \% 50'de konstipasyon görülmektedir (15). Kilo artışının temel sebebi olarak ince bağırsak atrofisinin düzelmesi ve yüksek yağ, yüksek karbonhidrat, yüksek glisemik indeks ve yoğun kalori içeren besinlerin tüketimi gösterilebilir (30, 40). Bu da GFD'ye geçişle birlikte kilo fazlalığı veya obezite riskini artırdığından, çocuklarda bireysel özellikler göz önünde tutularak diyetin planlanması ve uzun süreli takibinin yapılması gerekmektedir (44).

\section{Glutensiz Diyete Uyum}

Çölyak hastalarında glutensiz diyet çok iyi planlansa da uyum ile ilgili sorunlar yaşanmaktadır. Hastalarda diyeteuyumsuzluk \%20-80arasındadeğişmektedir(15, 45). En önemli uyumsuzluk nedenlerine bakıldığında; GFD sosyal yaşamı sınırlamakta, sınırlı besin alımı, glutensiz ürünlerin tatlarının farklı ve pahalı olması, uzun süreli takiplerinin zorlukları, diyet eğitimlerinin yetersizliği ve küçük miktarda bile gluten ihtiva eden besinlerin tüketiminin klinik atakları tetiklemesi olarak sıralanabilir. Yaşam tarzı değişiklikleri hem çocuk hem de ailede oluşmadığından da diyete uyum olumsuz etkilenmektedir $(45,46)$.

Hastaların ilk tanı sırasında diyet değerlendirmelerinin yapılması ve uygun diyet ile uyumları da artmaktadır. Çölyak hastalığı için tıbbi beslenme tedavisini diyetisyen planlamalı, yaşam tarzına ve tıbbi durumuna uygun bir GFD'e geçiş sağlanmalıdır (40). (Tablo 4)

Table 4. Çölyak Hastalığında Tıbbi Beslenme Tedavisinin Özeti

\begin{tabular}{lll}
\hline Ilk değerlendirme & Danışmanlık & Takip et \\
\hline Diyet geçmişi & Sıkı uyumun önemi & Ağırlık \\
24 saat hatırlama & Gluten Kaynak: gıda ve gıda dışı & Uyum \\
Takviyeler & GF alternatifleri & Anlama \\
Besin eksiklikleri & GF alternatifleri nerede satılır & Diyet yeterliliği, çeşitliliği \\
& Destek grupları & Başa çıkma becerileri \\
& Etiket okuma, alışveriş & Egzersiz \\
& Evde Yeme & Sorun giderme (kasıtlıgluten veya \\
& & kasıtsız gluten tüketimi için) \\
\hline
\end{tabular}


Table 5. Beslenme Takibi için Önerilen Zamanlama

Ne zaman?

Tanı

GFD başlandıktan sonra 6 . Ay

Tanı sonrası yıllık takipler
Nasıl ?

Doğru beslenme öyküsü

Beslenme durumunun değerlendirilmesi

Antropometrik ölçümler (ağırlık, boy, BKI)

Fizik muayene (malnütrisyon belirtilerine dikkat)
Ticari olarak üretilen glutensiz ürünler pahalıdır ve çoğu ailenin bu ürünleri alabilme olanakları da yeterli değildir (40). Özellikle ülkemizde glutensiz ürünler muadil ürünlere göre 2-3 kat daha pahalı olmakta, ailelerin bu ürünlerin temininde zorlanmaları diyete uyumu da zorlaştırmaktadır. Ülkemizde 29850 sayılı Sosyal Güvenlik Kurumu Sağlık Uygulama Tebliğine göre devlet desteği olarak 0-5 yaş için 78,75 TL, 5-15 yaş için 120 TL, 15 yaş üstü için 108,75 TL ödeme yapılmaktadır (47).

Sürekli uzun dönem izlem GFD ve beslenme yetersizlikleri ve / veya metabolik dengesizliklerin erken tanımlanması için önemlidir. İdeal olarak, ÇH ve GFD konusunda deneyimli bir diyetisyen sağlık ekibinin ayrılmaz bir parçası olmalıdır (30).

Beslenme durumu ve antropometrik ölçümler düzenli olarak değerlendirilmelidir (ağırlık, boy ve BKI). GFD'ye bağlılık değerlendirilmeli ve güvenli bir şekilde besin etiketlerini okuma, besin çeşitliliğini sağlama ve GFD'nin nasıl yorumlanacağı hakkında bilgi verilmelidir. Besin öğesi yetersizlikleri erken tanımlanmalı ve düzenli takibi yapılmalıdır (30). (Tablo 5)

\section{SONUÇ}

Glutensiz diyet, ÇH için mevcut tek tedavi yöntemidir. Çocukluk çağında maksimum büyüme ve gelişme evresinde besin ögesi yetersizlikleri ve dengesizliklerine yol açabileceği için çok dikkatli uygulanmalı ve yakın takibe alınmalıdır. Deneyimli bir diyetisyen eşliğinde hastaya özgü en uygun glutensiz besinlerin tercih etmek gerekmektedir. En kısa sürede ailelere GFD eğitimi ve net diyet tavsiyeleri vererek hem yaşam tarzı değişiklikleri oluşturmak hem de besin ögesi yetersizliklerinin önüne geçmek önemli bir adım olacaktır. Bu nedenle çölyak tanısı aldıktan hemen sonra ailelerin uzman diyetisyene yönlendirmek çocukların büyüme ve gelişmelerinin devam etmesine ve hastalığına uygun beslenme danışmanlığı almasına olanak sağlar.

\section{Çölyak Hastalığında Tıbbi Beslenme Tedavisinde Öneriler:}

- Yaşam boyu süren ve kesin bir diyet uygulanmalı

- Kontaminasyon riskine dikkat edilmeli, en küçük bulaşmada o besin diyetten çıkartılmalı

- Hasta ve hasta yakınına glutensiz diyet ayrıntılı anlatılmalı

- Hazır gıdalar/etiketsiz gıdalar ile ilgili riskler hasta ve ailesine örnekler ile anlatılmalı

- Doğal yiyeceklere yönlendirilmeli, aşırı kalori ve yağ alımı engellenmeli

- Pişirme/hazırlama sırasında riskler anlatılarak diyete uyumun gücü artırılmalı

- Vitamin-mineral takibi (Fe, Zn, Mg, Se, Ca, Vit-B, Vit- D) yapılmalı

- Büyüme gelişme izlenmeli

- Laktaz eksikliği (laktozsuz diyet) dikkate alınmalı

- Glutensiz diyete uyum sorgulanmalı

- Düzenli diyetisyen kontrolü sağlanmalıdır.

Çıkar Çatışması: Çalışmada herhangi bir çıkar çatışması yoktur.

Finansal Çıkar Çatışması: Çalışmada herhangi bir finansal çıkar çatışması yoktur.

Yazışma Adresi: Volkan Özkaya, Uludağ Üniversitesi Sağlık Uygulama Araştırma Merkezi Poliklinikler binası 2. Kat Çocuk Diyet Polikliniği Nilüfer/BURSA

Tel: 05533718188 e-posta: volkan.diyetisyen@gmail.com

\section{KAYNAKLAR}

1. Göral V, Yıldırım N, Kaplan A, et al. The frequency of gluten enteropathy disease. Akademik Gastroenteroloji Dergisi 2007;6(3):144-8.

2. Husby S, Koletzko S, Korponay-Szabó IR, et al. European Society for Pediatric Gastroenterology, Hepatology, and Nutrition guidelines for the diagnosis of coeliac disease. $\mathrm{J}$ Pediatr Gastroenterol Nutr 2012;54(1):136-60.

3. Aydoğdu S, Tümgör G. Çölyak hastalığı. Güncel Pediatri 2005; 2: 47-53.

4. Dalgıç B, Sarı S, Özcan B, et al. The evaluation of factors and symptoms related to celiac disease in Turkish children. Turk Arch Ped 2011;46:323-30.

5. Catassi C, Gatti S, Lionetti E. World perspective and celiac disease epidemiology. Dig Dis 2015;33:141-6.

6. Aziz I, Branchi F, Sanders DS. The rise and fall of gluten. Proceedings of the nutrition society 2015; 74: 221-6.

7. Tonutti E, Bizzaro N. Diagnosis and classification of celiac disease and gluten sensitivity. Autoimmun Rev 2014;13(45):472-6. 
8. Fasano A, Catassi C. Clinical practice: Celiac disease. N Engl J Med 2012;367:2419-26.

9. Ertekin V, Selimoğlu MA, Kardaş F, et al. Prevalence of celiac disease in Turkish children. $J$ Clin Gastroenterol 2005;39(8):689-91.

10. Demirçeken FG, Kansu A, Kuloğlu Z, et al. Human tissue transglutaminase antibody screening by immunochromatographic line immunoassay for early diagnosis of celiac disease in Turkish children. Turk J Gastroenterol 2008;19:14-21.

11. Rubio-Tapia A, Hill ID, Kelly CP, et al. American College of Gastroenterology. ACG clinical guidelines: Diagnosis and management of celiac disease. Am J Gastroenterol 2013; 108(5): 656-77.

12. Tovoli F, Masi C, Guidetti E, et al. Clinical and diagnostic aspects of gluten related disorders. World $\mathrm{J}$ Clin Cases 2015;3(3): 275-84.

13. Gibson PR, Muir JG, Newnham ED. Other Dietary Confounders: FODMAPS et al. Dig Dis 2015;33:269-76.

14. Volta U, Caio G, Tovoli F, et al. Non-celiac gluten sensitivity: Questions still to be answered despite increasing awareness. Cell Mol Immunol 2013;10(5):383-92.

15. García-Manzanares A, Lucendo AJ. Nutritional and dietary aspects of celiac disease. Nutr Clin Pract 2011;26(2):163-73.

16. Downey L, Houten R, Murch S, et al. Guideline development group. Recognition, assessment, and management of coeliac disease: Summary of updated NICE guidance. BMJ 2015;351:h4513.

17. Murch $S$, Jenkins $H$, Auth $M$, et al. Joint BSPGHAN and coeliac UK guidelines for the diagnosis and management of coeliac disease in children. Arch Dis Child 2013;98(10):80611.

18. Pinto-Sanchez MI, Verdu EF, Liu E, et al. Gluten introduction to infant feeding and risk of celiac disease: Systematic review and meta-analysis. Arch Dis Child 2013;98:806-11.

19. Ivarsson A, Hernell $O$, Nystrom L, et al. Children born in the summer have increased risk for coeliac disease. J Epidemiol Community Health 2003;57(1):36-9.

20. Stene LC, Honeyman MC, Hoffenberg EJ, et al. Rotavirus infection frequency and risk of celiac disease autoimmunity in early childhood: A longitudinal study. Am J Gastroenterol 2006;101(10):2333-40.

21. Mearin ML. Celiac disease: Prevention in children. Dig Dis 2015;33(2):162-6.

22. Akobeng AK, Ramanan AV, Buchan I, et al. Effect of breast feeding on risk of coeliac disease: A systematic review and meta-analysis of observational studies. Arch Dis Child 2006;91(1):39-43.

23. Theethira TG, Dennis M. Celiac disease and the gluten- free diet: Consequences and recommendations for improvement. Dig Dis 2015;33(2):175-82.

24. Makharia GK. Current and emerging therapy for celiac disease. Front Med (Lausanne). 2014;1:6.

25. Catassi C, Fabiani E, lacono G, et al. A prospective, doubleblind, placebo-controlled trial to establish a safe gluten threshold for patients with celiac disease. Am J Clin Nutr 200785(1):160-6.

26. Codex alimentarius commission. Draft revised codex standard for foods for special dietary use for persons intolerant to gluten. 2008;42-64.

27. Hill ID, Dirks MH, Liptak GS, et al. Guideline for the diagnosis and treatment of celiac disease in children: Recommendations of the North American Society for Pediatric Gastroenterology, Hepatology and Nutrition. J Pediatr Gastroenterol Nutr 2005;40(1):1-19.

28. MacCulloch, K, Rashid M. Factors affecting adherence to a gluten-free diet in children with celiac disease. Paediatr Child Health 2014;19(6):305-9.

29. Caponio F, Summo C, Clodoveo ML, et al. Evaluation of the nutritional quality of the lipid fraction of gluten-free biscuits. Eur Food Res Technol 2008;43:198.

30. Penagini F, Dilillo D, Meneghin F, et al. Gluten-free diet in children: An approach to a nutritionally adequate and balanced diet. Nutrients 2013;5(11):4553-65.

31. Ohlund $\mathrm{K}$, Olsson $\mathrm{C}$, Hernell $\mathrm{O}$, et al. Dietary shortcomings in children on a gluten-free diet. J Hum Nutr Diet 2010;23(3):294300.

32. Grehn S, Fridell K, Lilliecreutz M, et al. Dietary habits of Swedish adult celiac patients treated by a gluten-free diet for 10 years. Scand J Nutr 2001;45(4):178-82.

33. Anderson JW, Baird P, Davis RH Jr, et al. Health benefits of dietary fiber. Nutr Rev 2009;67(4):188-205.

34. Thompson T, Dennis M, Higgins LA, et al. Gluten-free diet survey: Are Americans with coeliac disease consuming recommended amounts of fibre, iron, calcium and grain foods? J Hum Nutr Diet 2005;18(3):163-9.

35. Shepherd SJ, Gibson PR. Nutritional inadequacies of the gluten-free diet in both recently-diagnosed and long-term patients with coeliac disease. J Hum Nutr Diet 2013;26(4):34958.

36. Theethira TG, Dennis M, Leffler DA. Nutritional consequences of celiac disease and the gluten-free diet. Expert Rev Gastroenterol Hepatol 2014;8(2):123-9.

37. Annibale B, Severi C, Chistolini A, et al. Efficacy of glutenfree diet alone on recovery from iron deficiency anemia in adult celiac patients. Am J Gastroenterol 2001;96(1):132-7.

38. Saturni L, Ferretti G, Bacchetti T. The gluten-free diet: Safety and nutritional quality. Nutrients 2010;2(1):16-34.

39. Thompson T. Folate, iron, and dietary fiber contents of the gluten-free diet. J Am Diet Assoc 2000;100(11):1389-96.

40. See J, Murray JA. Gluten-free diet: The medical and nutrition management of celiac disease. Nutrition in Clinical Practice 2006;21(1):1-15.

41. Friedman A. Micronutrient deficiencies in pediatric celiac disease. Infant, Child, \& Adolescent Nutrition 2012;4(3): 15667.

42. Farrell RJ, Kelly CP. Celiac sprue. N Engl J Med 2002;346:1808.

43. Kabbani TA, Goldberg A, Kelly CP, et al. Body mass index and the risk of obesity in coeliac disease treated with the gluten-free diet. Aliment Pharmacol Ther 2012;35:723-9.

44. Valletta E, Fornaro M, Cipolli M, et al. Celiac disease and obesity: Need for nutritional follow-up after diagnosis. Eur $\mathrm{J}$ Clin Nutr 2010;64:1371-2.

45. Kaukinen K, Lindfors $\mathrm{K}$, Novel treatments for celiac disease: Glutenases and beyond. Dig Dis 2015;33:277-81.

46. Samasca G, Sur G, Lupan L, et al. Gluten-free diet and quality of life in celiac disease. Gastroenterol Hepatol Bed Bench. 2014 Summer;7(3):139-43.

47. Sosyal Güvenlik Kurumu Başkanlığından: Sosyal Güvenlik Kurumu sağlık uygulama tebliğinde değişiklik yapılmasına dair tebliğ. 7 Ekim 2016. http://www.resmigazete.gov.tr/ eskiler/2016/10/20161007-12.htm 